\title{
PARQUE MINHOCÃO, SÃO PAULO - BRAZIL: A CASE STUdY ON URBAN REHABILITATION, PLACE-MAKING AND GENTRIFICATION
}

\author{
PARQUE MINHOCÃO, SÃO PAULO - BRASIL: UM ESTUdO DE CASO SOBRE \\ REQUALIFICAÇÃO URBANA, PLACE-MAKING E GENTRIFICAÇÃO
}

Debora Sotto ${ }^{1}$

\begin{abstract}
This paper consists of a case study on "Parque Minhocão", an urban rehabilitation project currently in the making in the city of São Paulo, Brazil. The "Minhocão" is a high track built in the 1970s to connect the west to the east districts through the city center. It has generated an extensive urban fracture as it degraded the neighborly quarters. Projects aimed at its demolition have been discussed since its inauguration but were never implemented; according to the city's 2014 Master Plan, a municipal law must determine the high track's final destination. As the population has been authorized to access the high track as a leisure site on weekends and holidays, public opinion has been divided between demolishing the structure or transforming it into a park. Urban social movements have been organized in favor of the demolition and the implementation of the park. In this context, our investigation aims to demonstrate how urban rehabilitation projects, apparently focused on place-making proposals, may result in gentrification, displacement and spatial injustice. To do so, we will examine, under a multidisciplinary perspective, not only the city's legislation, but also public documents, news reports, social media contents, followed by a revision of the relevant literature in planning law, urban planning and other applicable disciplines.
\end{abstract}

Keywords: Gentrification; Place-Making; Social Movements; Spatial Justice; Urban Rehabilitation

\section{Resumo}

Este trabalho trata de um estudo de caso sobre o "Parque Minhocão", um projeto de reabilitação urbana atualmente em construção na cidade de São Paulo, Brasil. O "Minhocão" é uma pista elevada construída nos anos 1970 para conectar os distritos da zona oeste aos distritos da zona leste de São Paulo através do centro da cidade, resultando em uma extensa fratura urbana ao degradar os bairros vizinhos. Projetos voltados à sua demolição foram discutidos desde a sua inauguração, mas nunca foram implementados. De acordo com o Plano Diretor Estratégico de 2014 da cidade de São Paulo, uma lei municipal deve determinar o destino final do elevado. Como a população foi autorizada a acessar o elevado como local de lazer nos fins de semana e feriados, a opinião pública se dividiu entre demolir a estrutura ou transformá-la em parque. Movimentos sociais urbanos foram organizados em favor tanto da demolição como da implementação do parque. Nesse contexto, nossa pesquisa tem como objetivo demonstrar como projetos de reabilitação urbana, aparentemente focados em propostas de place-making, podem resultar em gentrificação, deslocamentos forçados e injustiça espacial. Para tanto, analisaremos, sob uma perspectiva multidisciplinar, não apenas a legislação da cidade, mas também documentos públicos, notícias, conteúdos de mídias sociais,

\footnotetext{
1 Procuradora do Município de São Paulo (2003). Doutora em Direito Urbanístico pela PUC/SP (2015). Pesquisadora do Grupo de Pesquisa Meio Ambiente Urbano - GPMAU da PUC/SP (2011). E-mail: dsotto@hotmail.com
} 
seguidos de uma revisão da literatura relevante em direito urbanístico, planejamento urbano e outras disciplinas aplicáveis.

Palavras-chave: Gentrificação; Justiça Espacial; Movimentos Sociais; Place-Making; Requalificação Urbana.

\section{INTRODUCTION}

The "Minhocão", or "Elevado Costa e Silva", is an intra-urban high track built in the 1970s in the city of São Paulo, Brazil, to serve as a freeway connecting the west to the east districts, right through the city's historical center. As a result, it has produced an extensive urban fracture as it degraded the neighborly quarters, rapidly abandoned by resident upper class families and local businesses.

Due to the high track's devastating environmental impacts in the perimeter, projects aimed at its demolition have been discussed ever since its inauguration but were never implemented. As the population has been recently authorized to access the high track on weekends and holidays, turning it into a self-managed, collective place dedicated to leisure, sports and culture, the public opinion has been divided between demolishing the structure and transforming it into a park.

Residents, community leaders, entrepreneurs, scholars and activists have organized themselves in urban social movements pro-demolition and pro-park, seeking to foster placemaking measures and deal with the threat of gentrification, as new real estate developments are being launched in anticipation to the area's rehabilitation.

According to São Paulo's 2014 Master Plan, a municipal law must determine the high track's destination, an urban policy decision which can only be taken through an extensive participatory process. Nevertheless, the city's former and current Administrations have been signaling towards the implementation of the park to boost urban rehabilitation, regardless of the negative impacts it might have on the local low middle class residents and small businesses, as the area is already under incipient, yet consistent gentrification.

In this context, this paper main objective is to conduct a study on the "Minhocão" case under a multidisciplinary perspective, through the examination of São Paulo's 2014 Master Plan and 2016 Zoning Law, public documents, news reports, social media contents as well as the revision of relevant literature in planning law, urban planning and other applicable disciplines, in order to investigate how urban rehabilitation projects, apparently focused on place-making proposals, may result in displacement and gentrification, thus aggravating rather than 
alleviating spatial injustice in the city².

\section{THE "MINHOCÃO" HIGH TRACK'S INAUGURATION: A SYMBOL OF SPATIAL JUSTICE DURING THE MILITARY DICTATORSHIP}

The "Minhocão", or "Elevado Costa e Silva", is an intra-urban high track built in the early 1970s in the city of São Paulo, Brazil, above the Amaral Gurgel, São João, General Olímpio da Silveira and Francisco Matarazzo Avenues, to serve as a freeway connecting the west to the east districts through the city's historical center.

At the time, the country was under a military dictatorship: city mayors were not elected by the population, but appointed by the state's governors, who in turn were themselves appointed by the President. As popular participation in urban planning is rarely viable in nondemocratic regimes, the high track project was not discussed with the city's population. No public hearings or consultations were held. The project was unilaterally set up and implemented by the city's Administration, with no previous assessment of the negative impacts it might have in the neighborly areas, which, at the time, were an important territory for the music and the arts in the city. For this reason, the high track - which was named after Costa e Silva, the dictator who ruled the country from 1967 to 1969 - is an urban symbol of the dictatorship's power and oppression in the city (AB'SABER, 2016).

According to ROLNIK and KLINTOWITZ (2011, p. 93), the Minhocão high track is part of a set of road works implemented in the city of São Paulo in the 1960s and 1970s, based on Robert Moses' 1949 Public Improvements Plan. As the cited authors point out, Moses' Public Improvements Plan to São Paulo, inspired by his previous experience in New York, envisioned the construction of several freeways within the city, to operate independently in relation to the rest of the urban tissue in order to accommodate the heavy traffic directed to the city by the state highways and, at the same time, preserve the radio concentric structure previously set up by Prestes Maia's 1930 Avenues Plan. It is also important to highlight that, at the time the city of São Paulo had no Master Plan whatsoever: the city's first Master Plan would be edited only in 1972, by Mayor José Carlos Figueiredo Ferraz (SACONI; ENTINI, 2013).

The Minhocão high track, inaugurated in January $25^{\text {th, }} 1971$ by Mayor Paulo Maluf, is 3.4

\footnotetext{
2 This paper was presented, in a preliminary version, at the Urban Affairs Association 47 ${ }^{\text {th }}$ Annual Conference, held in Minneapolis in April 2017, as part of the Activist Scholarship Special Session: Grassroots Struggles for Employment and Agency in Urban Rehabilitation.
} 
kilometers long and 15 to 23 meters wide. Only five years after the inauguration, the city's Administration had to prohibit the traffic of vehicles during the night time, from $21 \mathrm{~h} 30$ until 6h30, as the noise and pollution made it impossible for the residents to rest (ASSOCIAÇÃO PARQUE MINHOCÃO, 2016).

Since its construction, the high track has significantly degraded the neighborly quarters, spawning an extensive urban fracture which has enhanced the decadence of São Paulo's historical center west sub-districts such as República, Santa Cecilia and Campos Elíseos, districts which had been home to part of the city's socio-economical elite at the beginning of the $20^{\text {th }}$ century. Not even the inauguration of an underground station in the 1980s, right at the high track's side at Marechal Deodoro Square, has succeeded to boost the area's revitalization (GORSKI, 2005).

As MARAFON and SILVA NETO (2017) point out, the high track's design - excessive low height and proximity to the neighboring buildings - has had an enormous impact to the local urban landscape, disfiguring the pre-existing city and potentiating urban disqualification, knocking down property and rent values, closing businesses and expelling the upper middle class original residents. In this context, paradoxically, the urban degradation induced by the Minhocão high track has had a social "positive" side effect (WHITAKER, 2014), as it has enabled the poor and marginalized to rent or even purchase depreciated residential units in the buildings alongside the Minhocão, and thus secure residence near their workplaces, in an area reasonably served with urban utilities and services ${ }^{3}$.

This succession of the fleeing elites by the urban poor in the decadent central neighborhoods, which can be observed throughout the historical city-center districts in São Paulo as well as in other Brazilian large cities, is a by-product of the peculiar dynamics of both formal and informal land markets operating in the city. According to ABRAMO (2007), the fictitious devaluating of the real estate stock in the formal market generates a series of cascaded spatial displacements of households and neighborhood externalities, from the top down to the bottom of the cities social hierarchy, causing both the ascension and the decline of urban districts and the displacement of the city's center, what opens space for the urban poor in the declining urban centralities.

\footnotetext{
${ }^{3}$ According to a research done by KARA JOSÉ (2010), between 1997 and 2007, there was a decrease of high income families in all the districts belonging to the historical center of São Paulo; at the same time, there was an increase of medium and low income families, more significantly so in the República district alongside part of the Minhocão High Track.
} 


\section{PLACE-MAKING IN QUESTION: CAN A HIGH-TRACK BECOME A PARK?}

Due to its environmental impacts, the high track's demolition has entered São Paulo's urban planning agenda since its very inauguration, but no consistent projects have thrived so far in that direction. In 2004, the Sé Sub-Prefecture Regional Plan - a strategic plan to São Paulo's central districts based on the 2002 Master Plan, valid until 2014 - has set some planning guidelines to the Minhocão high track, fostering the use of its structure for the installation of spaces for collective use and proposing the implementation of alternative road systems connecting the east and west portions of the city to render viable the high track's complete elimination.

Based on these legal provisions, a call for projects was issued by the Municipality in 2006, resulting on the presentation of 46 alternative solutions to the high track; a winning project was pronounced and 4 honorable mentions were granted (PREFEITURA DE SÃO PAULO, 2006). However, none of these projects were implemented by the city's Administration.

As of today, the Minhocão high track is still intensely used by automobiles heading to and from the west districts to the city center and farther on to the east districts, with a daily traffic of more than 70.000 vehicles (CÂMARA MUNICIPAL DE SÃO PAULO, 2016). Nevertheless, preliminary studies conducted by the Municipal Traffic Engineering Company - CET (Companhia de Engenharia de Tráfego) indicate that most of the trips taken in the Minhocão highway have migrated over time to the expanded Marginal Tietê - an expressway alongside Tietê River which also connects the east and west portions of the city. Therefore, the CET estimates that the six thousand vehicles circulating in both sides of the high track in the rush hour could be easily absorbed by the existing roads system in the environs, should the high track be deactivated (ANTP, 2015).

Parallel to that, as the population has been gradually granted access to the high track as a leisure site, firstly at nights, and later on also on Sundays and holidays, the public opinion has been divided between demolishing the structure and transforming it into a park. In a city that suffers heavily with the lack of qualified public spaces for leisure and recreation ${ }^{4}$, specially for the poor, the Minhocão has ultimately been claimed by the local population as a collective space for sports - walking, running, cycling, skating - and cultural expression - movies

\footnotetext{
${ }^{4}$ According to the Municipal Secretariat of the Environment, the city of São Paulo has an overall rate of $12,50 \mathrm{~m} 2$ of green space per inhabitant, barely the minimum of $12 \mathrm{~m} 2$ per inhabitant recommended by the World Health Organization - WHO (REDE NOSSA SÃO PAULO, 2012, p. 7).
} 
projections, graffiti, theatre presentations, martial arts, street markets and so forth (NOVA, 2015)

Acknowledging the site's new vocation, both public and private organizations have been hosting cultural events on the high track on weekends and holidays, what has brought on new pressures and influences on the environs, as this spontaneous place-making initiative has raised the attention of new players and stakeholders, from young professionals looking for cheap housing options in a central neighborhood, to developers and investors prospecting profitable business opportunities in the "renewed" city center, as empty lots and plots available for construction in the city central districts have been virtually exhausted within the last two decades.

Despite the economic crisis which has been affecting the country for the last few years, new real estate developments are being launched in the Minhocão's perimeter, in anticipation of its rehabilitation: older houses and parking lots alongside the high track are slowly giving place to new residential buildings, aimed at upper middle class buyers. At least 540 new residential units are currently under construction, right alongside the high track, nearby the subway stations of Marechal Deodoro and Santa Cecilia (CORREIA, 2014).

\section{URBAN REHABILITATION IN DISPUTE: URBAN SOCIAL MOVEMENTS PRO PARK AND PRO DEMOLITION}

In this new context, residents, community leaders, entrepreneurs, scholars and activists have organized themselves in urban social movements pro-demolition and pro-park, seeking to foster place-making measures and deal with the incipient gentrification of the neighborhood. Following what seems to be a global phenomenon these urban social movements use the internet and social Medias as preferred platforms for their mobilization.

NEL LO (2016) defines these urban movements as social movements that "take as their starting point the limitations and opportunities offered by the city and make a decisive contribution to the latter's configuration", in such a manner that they "can therefore be considered authentic urban agents, instrumental in shaping the city" (p.2). The same author observes that "the innovative use of social networks (by the urban movements) has become one of its main features" (p. 4).

The pro-park movement, named "Associação Amigos do Parque Minhocão", is organized as a non-profit civil association whose main objective is the implementation of a city 
park for pedestrians and cyclists in the high track. The association's internet platform is based on a web-site [http://www.minhocao.org] and on a Facebook page [https://www.facebook.com/Parque-Minhoc\%C3\%A3o-375353895931493/?fref=ts].

Amongst all the social movements implicated in the Minhocão case, the pro-park association is by far the best organized, with access to private funding and important connections with the local press, the City Council and the City Hall. Urban rehabilitation, placemaking and quality of life are the topics mostly argued by the association, whereas gentrification, displacement and other topics alike are carefully dismissed in the movement's discourse.

The High Line, in New York, is often cited by the pro-park movement, with significant support of the local press, as a virtuous example of what could be done with the Minhocão: not only its transformation into a park, but also its implementation and management by a nongovernmental organization with as minimum public intervention as possible is strongly advocated by the pro-park activists to foster the urban rehabilitation of the entire neighborhood (LORES, 2012).

It is no coincidence that the High Line is pointed out as a case of "environmental gentrification", as raising land values in the park surroundings have out priced and forced out many low-income residents and small businesses (HAFFNER, 2015). As CHECKER (2011, p.212) points out, "environmental gentrification builds on the material and discursive successes of the urban environmental justice movement and appropriates them to serve high-end redevelopment that displaces low income residents". That is exactly what the pro-demolition movement, opposed to the pro-park movement, is struggling to fight off.

The pro-demolition movement, named "Movimento Desmonte do Minhocão", is integrated mostly by local middle class/low-middle class residents and community leaders. Their main goals are to promote the high track's demolition to improve the quality of life to those who already live and work in the Minhocão environs and, at the same time, protect their right to remain in the area once it is rehabilitated ${ }^{5}$. Therefore, spatial justice, gentrification, displacement and urban land speculation are topics often argued in this movement's discourse. Due to limited financial resources, the pro-demolition movement is not formally organized as an association and disseminates its vision and actions mostly through internet tools: a web-site

\footnotetext{
${ }^{5}$ A documentary produced by a group of journalism graduates in 2015, "Ponto de Vista", shows the different perspectives around the Minhocão's rehabilitation process, through interviews held with Mayor Haddad, members of the local government, city councilors, residents and users. The documentary is available at: [https://youtu.be/FZrgLzHoKeU].
} 
[http://www.minhocao.net], a blog [http://desmonteminhocao.blogspot.com.br] and a Facebook page [http://www.facebook.com/movimentodesmontedominhocao].

There is still a third movement, whose main objective is to foster public debate to build up participatory and democratic solutions for the Minhocão, whether it is its dismantlement or its transformation into a park. This group, named "SP sem Minhocão", operates mostly as a debates circle, congregating various activists belonging to other social movements in the city. Urban rehabilitation, livability, gentrification, displacement, quality of life, land value speculation, all topics are discussed and debated by opposed activists in the group. Its main platform is a Facebook group page: [https://www.facebook.com/groups/714450381958504/], with approximately 1.725 members.

\section{THE MUNICIPALITY STEPS INTO THE DISPUTE: A CO-SPONSOR TO GENTRIFICATION?}

In July 2014, after intensive participatory procedures which lasted approximately eighteen months, the city of São Paulo managed to approve a new Master Plan, setting new lights on the Minhocão's future destination. Section 375 of the Master Plan, issued in the form of the Municipal Law n. 16.050/2014, has established that the Costa e Silva high track (Minhocão) must be gradually deactivated as a traffic lane to be finally demolished or transformed into a park, following the conditions and deadlines set by a specific municipal law to be eventually passed by the City Council.

At this point, it is important to clarify that Urban Planning, in Brazil, is mostly a local issue: according to the 1988 Brazilian Constitution, the urban development policy must be implemented by the Municipalities, following the guidelines set by national laws such as the 2001 Brazilian Statute of the City. The Constitution also points out the Masters Plans, issued by the Municipalities at the local level, as the basic (fundamental) urban policy tools in the country. Therefore, all Brazilian cities with a population superior to 20.000 inhabitants are obligated to enact their own Master Plans, following the essential guidelines and principles set by the national Statute of the City, including mandatory popular participation in all phases of the planning process ${ }^{6}$.

\footnotetext{
${ }^{6}$ Brazil was one of the first nations in the world to enact a national law recognizing the right to the city as a collective human right. According to section 2, item I of the Brazilian Statute of the City, edited in 2001, urban development must be oriented towards the realization of the "right to sustainable cities", legally
} 
Due to the provisions of the Statute of the City, not only the Master Plan, but also the Zoning Law, Building Codes and all other pieces of legislation regarding urban planning and urban development must be subjected to popular participation, through public hearings and consultations opened to all the implicated stakeholders, regardless of their status as "natural" or "legal persons", "residents", "voters" or "citizens". In Brazil, regardless of their legal status collective subjects often deprived of legal personalities - social movements not only can but must take an active role in the participatory urban planning process.

Therefore, any municipal laws deciding on the Minhocão high track's destination would have to be a by-product of public consultations, at the very least. Nevertheless, since the approval of the New Master Plan, the city's former Administration, which has ended its term in January 2017, had been consistently signaling towards the implementation of the park and implicitly discarding demolition.

In this context, since 2015, a series of vertical gardens has been installed on the windowless façades of buildings facing the Minhocão high track. According to procedures regulated by a Mayor's Decree issued in 2015 (Decree n. 55.994), the installation of these vertical gardens is financed with environmental compensations, paid to the Municipality by developers in exchange of the authorization to cut down trees in construction sites.

The destination of environmental compensation funds to finance vertical gardens is quite polemic, as many environmentalists consider that these gardens, despite their positive

defined as the sum of other collective human rights such as the right to urban land, housing, sanitation, transportation, urban utilities and services, labor and leisure, to the present and future generations. The right to participation is also a mandatory component of this "right to sustainable cities": according to section 2, item II of the Statute of the City, cities must be democratically managed, through the participation of the population and associations representative of the various segments of the community, in the formulation, implementation and monitoring of urban development plans, programs and projects. The Statute of the City is the result of decades of civil society mobilization towards the recognition of a democratic and inclusive legal urban agenda in Brazil. As a natural development to this historical activism in urban issues, several Brazilian NGOs, such as Instituto Pólis and Instituto Brasileiro de Direito Urbanístico - IBDU were actively engaged in the launching of the Global Platform for the Right to the City (GRP2C), an international network of civil society's organizations and local governments created in São Paulo in 2014 with the aim to promote the right to the city at local and international levels, including its recognition as a collective human right in the New Urban Agenda, what was actually accomplished in the Habitat III Conference in Quito, Ecuador, October 2016. Item 11 of the Quito Declaration on Sustainable Cities and Human Settlements for All states that "we share a vision of cities for all, referring to the equal use and enjoyment of cities and human settlements, seeking to promote inclusivity and ensure that all inhabitants, of present and future generations, without discrimination of any kind, are able to inhabit and produce just, safe, healthy, accessible, affordable, resilient and sustainable cities and human settlements to foster prosperity and quality of life for all. We note the efforts of some national and local governments to enshrine this vision, referred to as 'right to the city', in their legislation, political declarations and charters". 
effects on air pollution filtering, air humidity control and urban landscape, do not render the same environmental services as ground vegetation.

The first vertical garden in the Minhocão's perimeter was installed in September 2015, with an area of $302 \mathrm{~m}^{2}$ at a cost of approximately US\$84,000.00 (SECRETARIA EXECUTIVA DE COMUNICAÇÃO, 2015a). So far, seven vertical gardens have been installed alongside the Minhocão high track, forming up a "green corridor" with an area of $4.000 \mathrm{~m}^{2}$. The largest vertical garden was installed in December 2016, with an area of $1.500 \mathrm{~m}^{2}$, at a cost of approximately US\$750,000.00 in environmental compensations (NEVES, F., 2016).

Another initiative signaling towards the conversion of the high track into a park was the construction of a bicycle path, running mostly beneath the high track. This bicycle path, inaugurated in August 2015 at a cost of approximately US\$3.8million, is $4.1 \mathrm{~km}$ long and connects the Roosevelt Square, in the city center, with the Western Bus Terminal of Barra Funda (SECRETARIA EXECUTIVA DE COMUNICAÇÃO, 2015b).

Parallel to these "greening" initiatives taken by the City Hall, a bill proposing criteria to the high track's progressive deactivation and its provisional designation as a "park" was presented in February 2014 by seven city councilors with the support of the "Parque Minhocão" movement. An alternative bill was presented in August 2015, proposing only to change the High Track's name to "Parque Minhocão" (Minhocão Park) during the period it is closed to traffic and opened to people. In a legislative process that lasted approximately two years, with the active participation of pro-demolition and pro-park social movements in a few agitated public hearings, the alternative bill was finally approved by the City Council and sanctioned by the Mayor in March 9 $9^{\text {th, }} 2016$ in the form of the Municipal Law n. 16.397.

According to the City Hall public statements, the high track's change of designation is more than a mere technicality: it allows the constitution of a Management Council to the park and access to public funds to finance services such as lighting, sweeping, surveillance, and other necessities appointed by the park's users (SECRETARIA EXECUTIVA DE COMUNICAÇÃO, 2016). The initiative was obviously welcomed by the pro-park movement, and strongly criticized by pro-demolition activists, who denounced the lack of proper popular participation in the decision-making process.

To a local newspaper, former Mayor Haddad declared that the law's approval was a "step to call up society's attention and reeducate the city's outlook on the functions of space", highlighting that "any decision (regarding the high track's future) would have to be preceded by mitigation actions" in other to prevent "the region's gentrification, as we don't want to expel 
anyone from the environment" (ESTADÃO, 2016).

However, no active measures towards preventing gentrification in the Minhocão's area were taken by Haddad's administration. Quite the contrary: the vertical gardens, the bicycle path, music, arts and food truck festivals in the high track, all projects sponsored by the Municipality, have fostered the incipient but on-going gentrifying process in the district. The same can be stated in relation to the city's new Zoning Law, enacted by the Municipality in July 2016, right before the end of Haddad's term in the City Hall.

The city's new Zoning has delimited all blocks alongside both sides of the High Track as ZEM - "Zona Eixo de Estruturação da Transformação Metropolitana" (Structuring Axe to Metropolitan Transformation). According to section 6, item I of the Zoning Law, as ZEM, those blocks are considered "transformation territories": areas oriented towards high densities (no maximum height limits and maximum building potentials of four times the plot's area), diversified economic activities and public spaces qualification, to adjust land use patterns to the local offer to public transportation - bus corridors and subway stations. In other words, the 2016 Zoning Law aims to foster the area's rehabilitation through massive densification.

As MARCUSE (1985: 228) points out, the reduction or even the elimination of displacement, whether it is a by-product of gentrification or abandonment, is essentially a political choice, as "land use is an area in which government plays a significant regulatory role" and therefore "appropriate policies are not difficult to lay out". Appropriate policies meaning participatory planning, legal and fiscal regulations, which precisely as ZÁRATE (2015: 28) states "should be put in place with the required social control, to avoid speculation processes, both in the central areas as well as in peripheral zones".

Unfortunately, in the case of the Minhocão's perimeter, there seems to be an intentional detachment between the political discourse and the actual urban policy decisions (or choices) made so far by the city's Administration, all in favor of the area's urban rehabilitation regardless of its effects on the local population.

The last decision taken by the former municipal Administration concerning the Minhocão was the sanction of another local law in July 2016, changing the high track's name from "Elevado Costa e Silva" to "Elevado João Goulart", the President deposed by the military in 1964. This municipal Law, n. 16.525, was edited in the context of a broader project, conducted by the Municipal Secretariat of Human Rights, named "Ruas da Memória" (Streets of Memory).

In alignment with the works conducted from 2011 to 2014 by the Truth Commissions ("Comissões da Verdade") - civil society commissions organized by national, state and local 
governments to research and document human rights violations during the military dictatorship - the "Streets of Memory" project has mapped up more than 40 public places in the city named after people linked to the military dictatorship. Public consultations were held through an internet open Platform, to choose new names in substitution. The project's objective was not only to rename streets, avenues and squares, but to provide betterments such as lighting, gardening, and the installation of urban utilities to re-signify ${ }^{7}$ those places as public spaces (SECRETARIA DE DIREITOS HUMANOS E CIDADANIA, 2017).

This second change to the high track's name, from "Costa e Silva" to "João Goulart", was not as controversial as the change from "high track" to "park", partially because the high track has always been referred to by the population through its nickname "Minhocão" rather than "Elevado Costa e Silva". Nevertheless, the official name change has undoubtedly a significant symbolic weight, as it reinforces the city's on-going transition to democracy.

\section{THE CITY'S NEW ADMINISTRATION: PROSPECTS AND TENDENCIES}

In January 2017, a new Mayor has taken office in the City Hall. As required by legislation, in the first ninety days of the new Administration, a comprehensive Goals Plan, setting up strategic goals, lines of action and projects to the next four years (2017-2020), had to be drafted up and presented to City Council. Amongst the strategic goals eventually announced by Mayor João Dória on March 31 15t, 2017, one specific urban development goal was of special interest to the Minhocão case: the goal to implement urban rehabilitation projects in the city center, to promote its attractiveness, to increase land values and to foster quality of life and the adequate use of the available transportation infrastructure.

Even though the High Track was not expressly enlisted in the 2017-2020 Goals Plan amongst the foreseen rehabilitation projects, there is undoubtedly some alignment between the Goals Plan guidelines to the city center and the Zoning Law provisions on the Minhocão's perimeter: urban rehabilitation through intensive densification, fostering the increase of land values and, consequently, gentrification if other urban tools are not maneuvered to counterbalance displacement, such as value-capture taxation, social rentals, social housing developments and so forth. Until the conclusion of this paper, in April 2017, it was still uncertain

\footnotetext{
${ }^{7}$ As GORANSKY (2015: 54) points out: "a just city is a city that chooses to remember and share its history with the generations to come and exhibits its past in memory sites, in public places in which, at the same time, democratic values and human rights are promoted".
} 
whether the new Administration would be inclined towards demolishing the high track or implementing the park. Nevertheless, in February $7^{\text {th }}$ 2018, the City Council passed the Municipal Law n. 16.833, officially converting the high track into a park and prohibiting its demolition.

According to this new legislation, the park will be gradually implemented by the city's Administration, and the resulting impacts on the neighborhood will be addressed by an Urban Intervention Plan, to be designed by the city's Planning Secretariat in 720 (seven hundred and twenty) days from the publication of the law.

\section{CONCLUSIONS}

Through the analysis conducted in this brief case study, it is possible to conclude that there is an on-going battle for the urban land located in the Minhocão's perimeter. It is a battle fought in the political and digital arenas between residents and small businesses, new-comers, real estate developers, investors, scholars, activists and the local government, here comprised both the City Hall and the City Council. The high track's destination is surely dependent of its symbolic weight in the city's history and its newly found vocation as a collective place of leisure and encounter, are certainly important elements to the outcome of this battle. Place-making, whether through the high-track's demolition and the consequent rehabilitation of the avenues and pathways beneath it, or its transformation into a park, will determine the extension of the urban rehabilitation project to be finally implemented in the area. Nevertheless, local resistance against displacement, even though firmly grounded in the right to the city, seems unable to fight off gentrification, as the city's Administration is significantly inclined to promote the area's rehabilitation through massive densification, no matter its social costs, forcing a top-down political decision, rather than building a bottom-up solution through participatory planning. Despite the intense mobilization of the urban social movements implicated, it is uncertain whether popular participation, even if timely maneuvered through the right institutional channels, will be able to reverse the situation. In sum, a question remains to be answered: will the Minhocão become once again a symbol of spatial injustice in the city of São Paulo?

\section{REFERENCES}

ABRAMO, P. (2007). A cidade com-fusa. A mão inoxidável do mercado e a produção da 
estrutura urbana nas grandes metrópoles latino-americanas. Revista Brasileira de Estudos Urbanos e Regionais, vol.9, n.2. Rio de Janeiro: IPPUR, nov. 2007, p. 25/54.

AB'SABER, T. (2016). Conciliação, Regressão e Cidade. 1. ed. São Paulo: Editora da Cidade.

ANTP - ASSOCIAÇÃO NACIONAL DE TRANSPORTES PÚBLICOS (2015). Disputa por espaço em uma cidade em transformação. Available at: [http://antp.org.br/noticias/clippings/disputa-porespaco-em-uma-cidade-em-transformacao.html]. Accessed in September $3^{\text {rd }} 2016$.

ASSOCIAÇÃO PARQUE MINHOCÃO (2016). A história do Minhocão. Available at: [http://minhocao.org/a-historia-do-minhocao/]. Accessed in September $3^{\text {rd }} 2016$.

CÂMARA MUNICIPAL DE SÃO PAULO (2016). Especial Minhocão. Available at: [http://www.camara.sp.gov.br/especiaiscmsp/especial-minhocao/]. Accessed in March $25^{\text {th }}$, 2016.

CHECKER, M. (2011). Wiped Out by the "Greenwave": Environmental Gentrification and the Paradoxical Politics of Urban Sustainability. City \& Society, 23(2).

CORREA, V. (2014). No papel, 'parque' no Minhocão já atrai prédios. Folha de São Paulo, 31/08/2014. Available at: [http://tools.folha.com.br/print?site=emcimadahora\&url=http://www1.folha.uol.com.br/cotidia no/2014/08/1508500-no-papel-parque-no-minhocao-ja-atrai-predio...] . Accessed in September $3^{\text {rd }} 2016$.

ESTADÃO (2016). Haddad sanciona lei que cria Parque Minhocão e diz que via é um erro. O Estado de São Paulo, March 9th 2016. Available at: [http://noticias.uol.com.br/ultimasnoticias/agencia-estado/2016/03/09/haddad-sanciona-lei-que-cria-parque-minhocao-e-diz-quevia-e-um-erro.htm]. Accessed in September $3^{\text {rd, }} 2016$.

GORANSKI, M. (2015). Justice that Serves People, Not Institutions. In: GRIFFIN, T. et al. (2015). The Just City Essays. New York: JMBC; Next City; The Nature of Cities. p. 53-54.

GORSKI, M. (2005). Abaixo o elevado. O desmonte do Elevado Costa e Silva e o efeito catalisador para a revitalização do Centro. Minha Cidade, São Paulo, ano 06, n.061.02, Vitruvius, ago. 2005. Available at: [http://www.vitruvius.com.br/revistas/read/minhacidade/06.061/1970]. Accessed in September $3^{\text {rd, }} 2016$.

HAFFNER, J. (2015). The dangers of eco-gentrification: what's the best way to make a city greener? The Guardian, May $6^{\text {th }}$ 2015. Available at: [https://www.theguardian.com/cities/2015/may/06/dangers-ecogentrification-best-way-makecity-greener]. Accessed in April $2^{\text {nd }} 2017$.

KARA JOSÉ, B. (2010). A popularização do centro de São Paulo: um estudo de transformações ocorridas nos últimos 20 anos. Doctoral thesis. São Paulo: USP.

LORES, R. (2012). Parque suspenso em NY faz SP sonhar com transformação do Minhocão. Folha de São Paulo, 26/08/2012. Available at: [http://www1.folha.uol.com.br/serafina/2012/09/1142674parquesuspensoemnyfazspsonhar- 
com transformacaodominhocao.shtml]. Accessed in September $3^{\text {rd }} 2016$.

MARAFON, F.; SILVA NETO, M. (2017). O destino do Elevado Costa e Silva, o Minhocão. Uma decisão à luz do urbanismo. Arquitextos. Vitruvius, 200.03. Urbanismo. Ano 17, jan. 2017. Available at: [http://www.vitruvius.com.br/revistas/read/arquitextos/17.200/6394]. Accessed in March 25 2017.

MARCUSE, P. (1985). Gentrification, Abandonment, and Displacement: Connections, Causes, and Policy Responses in New York City, 28 WASH. U. J. URB. \& CONTEMP. L. 195. Available at: [http://openscholarship.wustl.edu/law_urbanlaw/vol28/iss1/4]. Accessed in September $3^{\text {rd, }}$ 2016.

NEL LO, O. (2016). Seven challenges for the study of urban movements. City, Territory and Architecture, 3(1), 1-6.

NEVES, F. (2016). Minhocão ganha novo jardim vertical e chega a $4.000 \mathrm{~m} 2$ de paredes verdes. Folha de São Paulo, 16/12/2016. Available at: [http://www1.folha.uol.com.br/cotidiano/2016/12/1841529-minhocao-ganha-novo-jardimvertical-e-chega-a-4000-m-de-paredes-verdes.shtml]. Accessed in March 31 2016.

NOVA, D. (2015). Quem são as pessoas que já estão usando o Minhocão como se fosse um parque. Available at: [http://www.hypeness.com.br/2015/07/quem-sao-as-pessoas-que-jaestao-usando-o-minhocao-como-se-fosse-um-parque/]. Accessed in September $3^{\text {rd }} 2016$.

REDE NOSSA SÃO PAULO (2012). Indicadores e Referências de Metas para São Paulo 2013-2016. São Paulo: Rede Nossa São Paulo.

SACONI, R.; ENTINI, C. (2013). Planejamento foi exceção na cidade que cresceu seguindo interesses dos proprietários de terrenos. O Estado de São Paulo, September $20^{\text {th }} 2013$. Avaliable at: $\quad$ [http://acervo.estadao.com.br/noticias/acervo,como-era-sao-paulo-sem-planodiretor,9276,0.htm]. Accessed in March 25 2017.

SECRETARIA DE DIREITOS HUMANOS E CIDADANIA (2017). Ruas de Memória. Available at: [http://www.prefeitura.sp.gov.br/cidade/secretarias/direitos_humanos/direito_a_memoria_e_ a_verdade/programas_e_projetos/index.php?p=221739]. Accessed in April 1 2017.

SECRETARIA EXECUTIVA DE COMUNICAÇÃO (2015a). Empresa vai investir na construção de 40 jardins verticais. Available at: [ http://www.capital.sp.gov.br/portal/noticia/6143\#ad-image-0]. Accessed in September $3^{\text {rd }} 2016$.

SECRETARIA EXECUTIVA DE COMUNICAÇÃO (2015b). Prefeitura inaugura ciclovia do Minhocão. Available at: [http://www.capital.sp.gov.br/portal/noticia/5899\#ad-image-0]. Accessed in September $3^{\text {rd }} 2016$.

SECRETARIA EXECUTIVA DE COMUNICAÇÃO (2016). Haddad sanciona lei municipal sobre o "Parque Minhocão". Available at: [http://capital.sp.gov.br/portal/noticia/9650\#ad-image-0]. Accessed in April $1^{\text {st }} 2017$.

PREFEITURA DE SÃO PAULO (2006). Prefeitura anuncia vencedores do "Prêmio Prestes Maia de 
Urbanismo".

Available

at:

[http://www.prefeitura.sp.gov.br/cidade/secretarias/comunicacao/noticias/?p=134606].

Acessed in March 25 2017.

PREFEITURA DE SÃO PAULO (2017). Programa de Metas 2017-2020. São Paulo: Prefeitura de São Paulo, 2017. Available at: [http://www.camara.sp.gov.br/wpcontent/uploads/2017/03/PMSP_Programa-de-Metas-2017-2020.pdf]. Accessed in April $1^{\text {st }}$ 2017.

ROLNIK, R.; KLINTOWITZ, D. (2011). Mobilidade na cidade de São Paulo. Estudos Avançados 25 (71), 2011. p. 89-108.

WHITAKER, J. (2014). Maluf, o Minhocão e a gentrificação. Available at: [http://cidadesparaquem.org/blog/2014/8/22/maluf-o-minhoco-e-a-gentrificao]. Accessed in September $3^{\text {rd, }} 2016$.

ZÁRATE, L. (2015). Right to the City for All: A Manifesto for Social Justice in an Urban Century. In: GRIFFIN, T. et al. (2015). The Just City Essays. New York: JMBC; Next City; The Nature of Cities. p. 26-29.

Trabalho enviado em 02 de maio de 2018.

Aceito em 24 de julho de 2018. 